\title{
Higher yield, profit and soil quality from organic farming of elephant foot yam
}

\author{
Girija Suja • Sukumaran Sundaresan • \\ Kuzhivilayil Susan John • Janardanan Sreekumar • \\ Raj Sekhar Misra
}

Accepted: 18 September 2011 /Published online: 14 October 2011

(C) INRA and Springer-Verlag, France 2011

\begin{abstract}
Alternative agricultural systems, like organic farming, that are less chemical intensive, less exploitative and environment friendly are gaining popularity. Elephant foot yam (Amorphophallus paeoniifolius (Dennst.) Nicolson) is an important starchy tuberous vegetable with high nutritive and medicinal values. Since information on the organic farming of tuberous vegetables is scanty, field experiments were conducted in this crop at the Central Tuber Crops Research Institute, India, over a 5-year period. The impact of organic, conventional, traditional and biofertilizer production systems on growth, yield, quality, soil physico-chemical properties and economics were evaluated in elephant foot yam. Our results show that organic farming favoured canopy growth, corm biomass and lowered collar rot disease. Dry matter and starch contents of organic corms were significantly higher than those of conventional corms by $7 \%$ and $13 \%$, respectively. Organic corms had $12 \%$ higher crude protein and $21 \%$ significantly lower oxalate contents. The content of $\mathrm{K}, \mathrm{Ca}$ and $\mathrm{Mg}$ in corms were slightly higher, by $3-7 \%$ under organic farming. After 5 years of farming, the organic plots showed significantly higher $\mathrm{pH}$, by 0.77 unit, and higher organic $\mathrm{C}$ by $19 \%$. The exchangeable $\mathrm{Mg}$, available $\mathrm{Cu}, \mathrm{Mn}$ and $\mathrm{Fe}$ contents were also significantly higher. Organic management lowered the bulk density by $2.3 \%$, improved the water-holding capacity by $28.4 \%$ and the porosity of soil by $16.5 \%$. In short, organic farming proved superior and produced 20\% higher yield $(57.097 \mathrm{t}$ $\mathrm{ha}^{-1}$ ) over conventional practice $\left(47.609\right.$ tha $\left.^{-1}\right)$. The net
\end{abstract}

G. Suja $(\bowtie) \cdot$ S. Sundaresan $\cdot$ K. S. John $\cdot$ J. Sreekumar •

R. S. Misra

Central Tuber Crops Research Institute, Sreekariyam,

Thiruvananthapuram 695 017, Kerala, India

e-mail: sujagin@yahoo.com profit was $28 \%$ higher and an additional income of Indian Rs. $47,716 \mathrm{ha}^{-1}$ was obtained. Thus organic farming was found to be an eco-friendly management strategy in elephant foot yam for sustainable yield of quality tubers and higher profit besides maintaining soil health. Technologies for organic production involving farmyard manure incubated with bioinoculants, green manuring, neem cake, biofertilizers and ash were also standardized.

Keywords Amorphophallus paeoniifolius · Organic . Conventional · Corm yield · Dry matter · Starch · Oxalate . Soil physico-chemical properties $\cdot$ Income

\section{Introduction}

Currently there is considerable interest among farmers, researchers, governmental agencies and environmental conservation groups in investigating and adopting ecofriendly farming strategies. These strategies are less exploitative, less chemical intensive, less dependent on nonrenewable fossil fuels like fertilizers, pesticides, etc. and can conserve the precious soil and water resources. High input conventional agriculture using large-scale chemical inputs and few $\mathrm{C}$ additions silently results in irrevocable ecological and environmental catastrophes such as soil erosion, salinisation, receding ground water table, deterioration of soil fertility especially decline in organic $\mathrm{C}$ levels, nutrient imbalance, pesticide pollution, desertification, loss of biodiversity, damage to soil health and human health (Andrews et al. 2002; Chhonkar 2008).

Organic farming is an alternative farming strategy that focuses on soil health, environmental protection and human health by largely excluding the use of synthetic chemicals and with maximum use of on-farm-generated resources. 
Though the use of chemical inputs cannot be altogether avoided, their use in agriculture has to be rationalized. Organic farming gives a solution to some of the problems by reducing energy use and $\mathrm{CO}_{2}$ emissions besides offering opportunities for employment generation, waste recycling and export promotion (Reganold et al. 2001; Stockdale et al. 2001). The high-quality, nutritious and safe organic foods fetch a premium price in world markets. Thus the growing public concern about environmental and personal health issues have generated great consumer interest in organic farming and organically produced foods.

Elephant foot yam (Amorphophallus paeoniifolius (Dennst.) Nicolson) is an important tropical tuber crop popular as a food security crop and as a remunerative cash crop (Fig. 1). Its corms are rich in starch which is used as a vegetable having high nutritive value, good taste and cooking quality besides having medicinal values (Fig. 2). The corms also contain moderate amounts of protein, $\mathrm{Ca}$ and vitamin $\mathrm{C}$. The crop has a high production potential. It has great scope for commercial exploitation as a medicinal crop in pharmacological industry due to the presence of various nutraceuticals and the corms find wider use in traditional ayurvedic preparations for the treatment of inflammation, piles and gastrointestinal disorders (Regu et al. 1999).

Tropical tuber crops in general and edible aroids like elephant foot yam in particular, respond well to organic manures. Hence, there is ample scope for organic production in these crops (Suja et al. 2006; Suja 2008). In addition, there is a great demand for organically produced tuberous vegetables, among Asians and Africans living in Europe, USA and Middle East.

Very few reports on organic farming of tropical tuber crops are available at present. Questions still remain on the effect of organic management on growth, yield, soil properties and economics. Therefore the objectives of the experiment were to compare the effects of organic, traditional and conventional production systems on growth, yield and quality attributes of elephant foot yam as well as

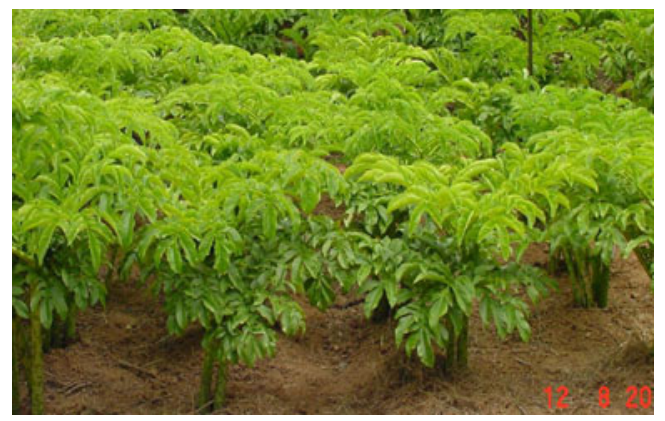

Fig. 1 Crop stand of elephant foot yam

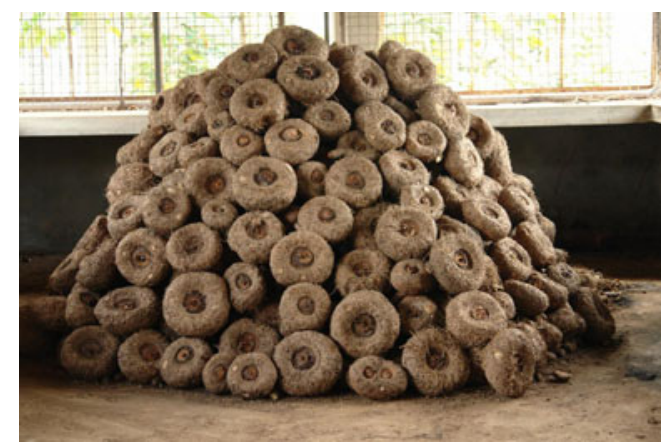

Fig. 2 Heaped organic corms

on soil physico-chemical properties and microbial count. The study also explored the comparative economic advantage of organic farming over conventional practice in elephant foot yam.

\section{Materials and methods}

\subsection{Site description, experimental design and test variety}

Field experiments were conducted for five consecutive years (during March-December from 2004 to 2008) at the Central Tuber Crops Research Institute, Thiruvananthapuram $\left(8^{\circ} 29^{\prime} \mathrm{N}, 76^{\circ} 57^{\prime} \mathrm{E}, 64-\mathrm{m}\right.$ altitude), India in an acid ultisol ( $\mathrm{pH} 4.23$ ). Cropping history of the land used for organic farming experimentation was such that after a single crop of sweet potato (June-July to August-September 2002) the land was left fallow for the remaining period. Thereafter two crops of green manure cowpea was raised and incorporated during 2003-2004 prior to the experimentation. Thus the land was slowly converted and not subjected to any chemical inputs for 2 years before taking up the study. In general, the fertility status of the soil was high for organic $\mathrm{C}$, available $\mathrm{P}$ and $\mathrm{K}$. Before green manuring, the organic $\mathrm{C}$ status was $1.026 \%$, the available $\mathrm{N}, \mathrm{P}$ and $\mathrm{K}$ contents were $329.38,79.64$ and $253.49 \mathrm{~kg} \mathrm{ha}^{-1}$, respectively. After green manuring, the organic $\mathrm{C}$, available $\mathrm{P}$ and $\mathrm{K}$ status were enhanced to $1.319 \%, 142.06$ and $527.80 \mathrm{~kg} \mathrm{ha}^{-1}$, respectively. The available $\mathrm{N}$ content was low $\left(255.61 \mathrm{~kg} \mathrm{ha}^{-1}\right)$. The site experiences a typical humid tropical climate. The mean annual rainfall was $1,853.89 \mathrm{~mm}$, maximum and minimum temperatures were $31.17^{\circ} \mathrm{C}$ and $24.97^{\circ} \mathrm{C}$, respectively, and relative humidity was $75.41 \%$. The total rainfall remained constant and fairly high during most years of experimentation $(1,860-2,100 \mathrm{~mm})$, except a decline $(1,258 \mathrm{~mm})$ during 2007.

The impact of four production systems viz., conventional, traditional, organic farming and using biofertilizers on 
growth, yield and quality of elephant foot yam as well as on physico-chemical properties of soil and microbial count was evaluated in RBD with five replications. The gross plot size was $4.5 \times 4.5 \mathrm{~m}$ ( 25 plants) accommodating nine net plants. In "conventional plots" the package of practices recommendations was advocated $\left(25 \mathrm{tha}^{-1}\right.$ farmyard manure +NPK 100:50:150 $\mathrm{kg} \mathrm{ha}^{-1}$ ). Farmers' practice of using farmyard manure (FYM; 35 tha $^{-1}$ ) and ash $\left(3\right.$ tha $\left.^{-1}\right)$ was followed in "traditional plots". In "organic farming plots", FYM at the rate of 36 tha $^{-1}$ (cowdung + neem cake mixture (10:1) inoculated with Trichoderma harzianum), green manure cowpea to yield 20-25 tha ${ }^{-1}$ of green matter, 3 tha $^{-1}$ of ash and 1 tha $^{-1}$ of neem cake were applied to substitute chemical fertilizers. Care was taken to avoid the use of any chemical inputs in organic plots. In plots assigned for evaluating the effect of biofertilizers, FYM $25 \mathrm{tha}^{-1}$, mycorrhiza $5 \mathrm{~kg} \mathrm{ha}^{-1}$, Azospirillum $3 \mathrm{~kg} \mathrm{ha}^{-1}$ and phosphobacterium $2.5 \mathrm{~kg} \mathrm{ha}^{-1}$ were applied. Organically produced corms of a locally popular variety of elephant foot yam, procured from Peermade Development Society, Idukki, Kerala, India, were used for the study.

\subsection{Field management}

Elephant foot yam was planted in plots of size $4.5 \times 4.5 \mathrm{~m}$. Corm pieces of $500 \mathrm{~g}$ with a portion of the terminal bud were planted in pits of $60 \times 60 \times 45$-cm size. The plant to plant distance was $90 \mathrm{~cm}$. Field culture was done in accordance with the package of practices of KAU (2002). The crop was planted during March in each year, mainly rain-fed and harvested after 9 months. In organic farming plots, green manure cowpea was sown twice viz., prior to experimentation and immediately after planting elephant foot yam in between the pits. The green matter was incorporated at $50 \%$ flowering stage during both the occasions. The quantity of green matter incorporated was $22.45,29.65,18.25,20.75$ and 22.25 tha $^{-1}$ in 2004,2005 , 2006, 2007 and 2008, respectively.

\subsection{Plant and soil measurements}

Growth Growth characters such as plant height, leaf spread and girth of pseudo-stem were measured from three plants at 3, 6 and 9 months after planting during all the years, mean values were computed and expressed in centimetres. Throughout the growth period, the crop was monitored for the occurrence of pest and disease incidence, especially collar rot caused by Sclerotium rolfsii, if any.

Biomass The total biomass production and its partitioning to different plant parts were studied by conducting biomass harvests of three plants at random from each plot at harvest.
Plants were separated into shoot and corm, air dried and then oven dried at $70^{\circ} \mathrm{C}$ to constant weight. Dry weight of these plant parts was recorded and the total plant dry weights were computed.

Yield Corms from the net plot were harvested, fresh weights were recorded and corm yield was expressed in ton per hectare.

Quality Proximate analyses of corms for dry matter, starch, total sugar, reducing sugar, crude protein, oxalates and total phenols were done using standard procedures. Dry matter, crude protein and oxalates were determined by the method of AOAC (1980). The starch content was determined by conversion to sugars by acid hydrolysis and then by the method of Dubois et al. (1956). Total sugars were also determined by the same method. Reducing sugars was estimated by the method of Nelson (1944) and total phenols by the method of Swain and Hillis (1955). Mineral composition of corms viz., $\mathrm{P}, \mathrm{K}, \mathrm{Ca}, \mathrm{Mg}, \mathrm{Cu}, \mathrm{Zn}, \mathrm{Mn}$ and $\mathrm{Fe}$ contents were also determined by standard methods (Piper 1970). The P content of corms was determined by the method of colorimetry, $\mathrm{K}$ and $\mathrm{Ca}$ by flame photometry, $\mathrm{Mg}, \mathrm{Fe}, \mathrm{Mn}, \mathrm{Zn}$ and $\mathrm{Cu}$ by direct reading in atomic absorption spectrophotometer.

Soil properties The $\mathrm{pH}$, organic C, available N, P, K, Ca, $\mathrm{Mg}, \mathrm{Cu}, \mathrm{Zn}, \mathrm{Mn}$ and $\mathrm{Fe}$ status of the soil were estimated by standard analytical methods (Page et al. 1982). Physical characters of the soil such as bulk density, particle density, water-holding capacity and porosity were estimated by the methods of Gupta and Dakshinamoorthy (1980). Microbial plate count of bacteria, fungi and actinomycetes were determined by the standard procedures described by Timonin (1940).

\subsection{Cost benefit analysis}

Total cost of cultivation and gross returns were calculated from average input cost and average market price of the produce during the period of investigation. Based on this net income was computed as follows:

Net income $\left(\right.$ Indian Rupees ha $\left.{ }^{-1}\right)=$ Gross income - cost of cultivation

\subsection{Statistical analyses}

The analysis of variance of data was done using SAS (2008) by applying analysis of variance technique (ANOVA) for randomised block design and pooled analysis of data of 5 years was also done. 


\section{Results and discussion}

\subsection{Canopy growth and general plant health}

Production systems $x$ year interaction was absent in the present study. Hence, pooled means of canopy growth characters viz., plant height, leaf spread and girth of pseudostem, at 3, 6 and 9 months during the 5 years under the various production systems were compared (Table 1). Plant height and girth of pseudostem were not significantly influenced by the various production systems particularly during the early months. However, they were promoted in organic plots. Leaf spread was found to be profoundly influenced by the production systems throughout the growth cycle. Organically grown and conventionally raised plants were comparable in leaf spread during the first two stages. However by the last stage, organic plants showed luxuriant growth, resulting in significantly greater height and leaf spread (Table 1). This may be due to the better moisture retention and improved soil properties under organic manuring. Mahapatra et al. (2006a) also reported that growth parameters of rice improved under organic management.

During the first year, the incidence of collar rot was almost the same under the different production systems. But organic and traditional plots showed lower incidence (Table 1). During the subsequent years of study, inoculation of farmyard manure using T. harzianum culture could further lower the disease incidence.

\subsection{Biomass production and partitioning}

The pattern of biomass production and partitioning was studied during the 5-year period. In the first year, corm biomass and whole plant biomass of organic plants were higher, but on a par with that of conventional plants. In the second year, corm biomass and whole plant biomass of organic plants were significantly higher. By the third year, biomass production and partitioning was not significantly influenced by treatments. But total biomass and its partitioning to corms were favoured by the conventional practice. Considering the average of 3 years, organic farming resulted in significantly higher whole plant biomass and corm biomass (Fig. 3). The general growth promoting effect of organic manures might have contributed to greater total biomass production and its effective partitioning for storage in the corms. However, the shoot biomass was not significantly affected by the different production systems during all the years.

\subsection{Soil chemical properties}

There was a steady improvement in the $\mathrm{pH}$ of the soil during the first 4 years in all plots and slight decline after 5 years. This increase was more pronounced in organic plots. Organic $\mathrm{C}$ status showed increment and decrement in alternate years in all the treatments. However, higher organic $\mathrm{C}$ status was maintained in organic plots than the rest. Available $\mathrm{N}$ also followed a similar trend, but for the severe drop after 5 years. Except during the first year, organic plots had higher available $\mathrm{N}$ status, which may be due to substantial input of $\mathrm{N}$ from different organic manures especially green manure cowpea, synchrony in the demand and rate of release of $\mathrm{N}$ from organic manures, negligible loss of $\mathrm{N}$ through different pathways such as leaching, volatilization, etc. when compared to $\mathrm{N}$ from fertilizer. In general, available $\mathrm{P}$ status of the soil was high that was maintained throughout the study period in all the production systems, except the third year, when there was a decline. Available K, which is crucial for high $\mathrm{K}$ consuming tuber crops like elephant foot yam, was also found to steadily increase during the first 3 years, decline after 4 years and again increase in all the plots. In general the status was high and the increment was more pronounced in organic plots (Fig. 4).

Table 1 Impact of production systems on growth characters of elephant foot yam (mean of 5 years)

\begin{tabular}{|c|c|c|c|c|c|c|c|c|c|c|}
\hline \multirow[t]{2}{*}{ Treatments } & \multirow{2}{*}{$\begin{array}{l}\text { Plant } \\
\text { height } \\
(\mathrm{cm})\end{array}$} & \multicolumn{3}{|l|}{3 months } & \multicolumn{3}{|l|}{6 months } & \multicolumn{2}{|l|}{9 months } & \multirow{2}{*}{$\begin{array}{l}\text { Collar rot } \\
\text { incidence }(\%)^{\mathrm{a}}\end{array}$} \\
\hline & & $\begin{array}{l}\text { Pseudo } \\
\text { stem girth } \\
(\mathrm{cm})\end{array}$ & $\begin{array}{l}\text { Leaf } \\
\text { spread } \\
(\mathrm{cm})\end{array}$ & $\begin{array}{l}\text { Plant } \\
\text { height } \\
(\mathrm{cm})\end{array}$ & $\begin{array}{l}\text { Pseudo } \\
\text { stem girth } \\
(\mathrm{cm})\end{array}$ & $\begin{array}{l}\text { Leaf } \\
\text { spread } \\
(\mathrm{cm})\end{array}$ & $\begin{array}{l}\text { Plant } \\
\text { height } \\
(\mathrm{cm})\end{array}$ & $\begin{array}{l}\text { Pseudo } \\
\text { stem girth } \\
(\mathrm{cm})\end{array}$ & $\begin{array}{l}\text { Leaf } \\
\text { spread } \\
(\mathrm{cm})\end{array}$ & \\
\hline Conventional & $38.52 \mathrm{a}$ & $14.08 \mathrm{a}$ & $96.85 \mathrm{ab}$ & $50.19 \mathrm{a}$ & $13.77 \mathrm{a}$ & $105.67 \mathrm{~b}$ & 69.79 a & $12.28 \mathrm{a}$ & $108.65 \mathrm{a}$ & $20.73(27.08) \mathrm{a}$ \\
\hline Traditional & $38.49 \mathrm{a}$ & $13.72 \mathrm{a}$ & $93.00 \mathrm{~b}$ & $48.04 \mathrm{a}$ & $13.43 \mathrm{a}$ & $99.08 \mathrm{a}$ & $69.63 \mathrm{a}$ & $11.47 \mathrm{a}$ & $105.15 \mathrm{a}$ & $11.88(20.16) \mathrm{a}$ \\
\hline Organic & $39.63 \mathrm{a}$ & $14.55 \mathrm{a}$ & $100.17 \mathrm{a}$ & $51.08 \mathrm{a}$ & $14.00 \mathrm{a}$ & $109.23 \mathrm{~b}$ & $74.01 \mathrm{~b}$ & $12.29 \mathrm{a}$ & $115.72 \mathrm{~b}$ & 11.33 (19.68) a \\
\hline Biofertilizers & $37.49 \mathrm{a}$ & $13.79 \mathrm{a}$ & $94.84 \mathrm{~b}$ & $47.27 \mathrm{a}$ & $13.54 \mathrm{a}$ & $99.25 \mathrm{a}$ & $67.78 \mathrm{a}$ & $11.65 \mathrm{a}$ & $103.41 \mathrm{a}$ & $15.27(23.00) \mathrm{a}$ \\
\hline$P$ values & 0.253 & 0.070 & 0.025 & 0.102 & 0.449 & 0.001 & 0.021 & 0.114 & 0.001 & NS \\
\hline
\end{tabular}

Months refers to months after planting. Organic management produced luxuriant crop stand and lowered collar rot incidence

Values followed by a similar letter are not significantly different

${ }^{a}$ Figures in parentheses are transformed means in angles 


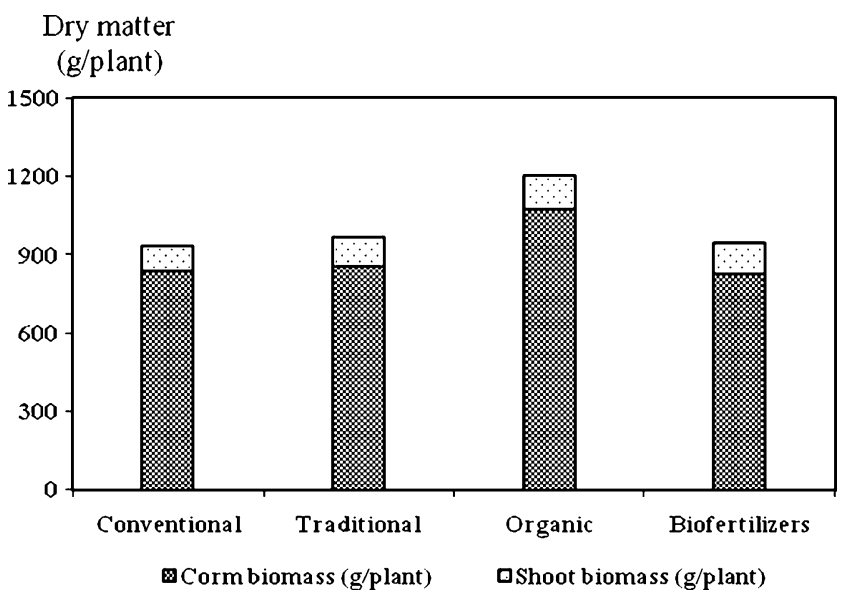

Fig. 3 Effect of production systems on dry matter distribution in elephant foot yam (mean of 3 years)
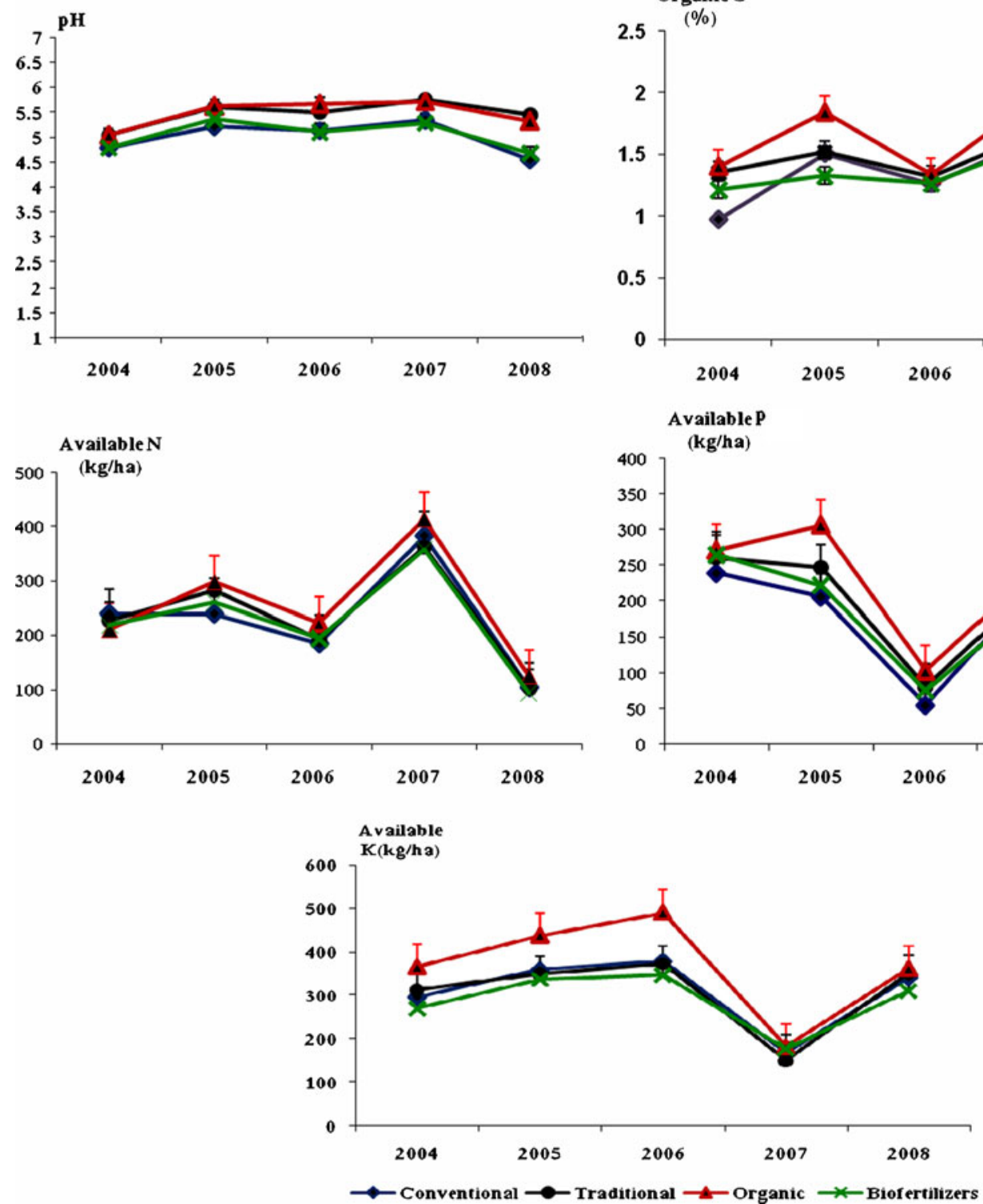

Fig. 4 Pattern of $\mathrm{pH}$, organic $\mathrm{C}$ and major nutrients in soil as affected by production systems over 5 years
The year wise pattern of the impact of treatments indicates that at the end of first year, organic $\mathrm{C}, \mathrm{pH}$, available $\mathrm{N}, \mathrm{P}$ and $\mathrm{K}$ were not significantly influenced by the different production systems. However, organic plots showed slightly higher $\mathrm{pH}$, organic $\mathrm{C}$, available $\mathrm{P}$ and $\mathrm{K}$ status.

After 2 years, $\mathrm{pH}$, organic $\mathrm{C}$, available $\mathrm{P}$ and $\mathrm{K}$ status of the soil were significantly higher in organic plots. After 3 years, organic plots showed significantly higher available $\mathrm{P}$ and $\mathrm{pH}$, slightly higher organic $\mathrm{C}$, available $\mathrm{N}$ and $\mathrm{K}$ status. At the end of fourth year, organic plots showed significantly higher $\mathrm{pH}$ and slightly higher organic $\mathrm{C}$, available $\mathrm{N}, \mathrm{P}$ and $\mathrm{K}$ status. The post experiment nutrient status after 5 years indicated that $\mathrm{pH}$ was influenced by the various practices and was significantly higher in organic and traditional plots. Organic C, available N, P and K status
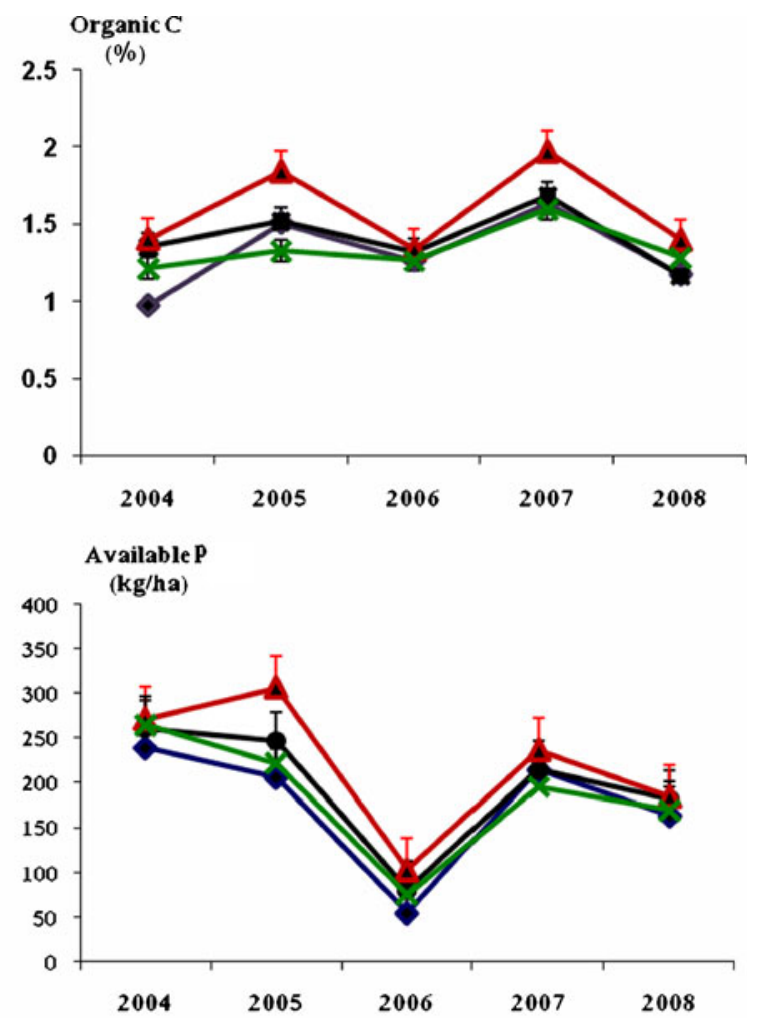
Table 2 Effect of production systems on the status of secondary and micro-nutrients of soil at the end of 5 years

\begin{tabular}{lcccccc}
\hline $\begin{array}{l}\text { Production } \\
\text { systems }\end{array}$ & $\begin{array}{l}\text { Exchangeable } \mathrm{Ca} \\
\left(\mathrm{kg} \mathrm{ha}^{-1}\right)\end{array}$ & $\begin{array}{l}\text { Exchangeable } \mathrm{Mg} \\
\left(\mathrm{kg} \mathrm{ha}^{-1}\right)\end{array}$ & $\begin{array}{l}\text { Available } \mathrm{Cu} \\
(\mathrm{ppm})\end{array}$ & $\begin{array}{l}\text { Available } \mathrm{Zn} \\
(\mathrm{ppm})\end{array}$ & $\begin{array}{l}\text { Available Mn } \\
(\mathrm{ppm})\end{array}$ & $\begin{array}{l}\text { Available Fe } \\
(\mathrm{ppm})\end{array}$ \\
\hline Conventional & $659 \mathrm{a}$ & $28.7 \mathrm{~b}$ & $1.5 \mathrm{~b}$ & $2.9 \mathrm{a}$ & $8.0 \mathrm{c}$ & $56.9 \mathrm{c}$ \\
Traditional & $847 \mathrm{a}$ & $41.0 \mathrm{a}$ & $2.4 \mathrm{~b}$ & $3.8 \mathrm{a}$ & $11.3 \mathrm{bc}$ & $63.3 \mathrm{bc}$ \\
Organic & $813 \mathrm{a}$ & $39.7 \mathrm{a}$ & $3.6 \mathrm{a}$ & $4.1 \mathrm{a}$ & $17.4 \mathrm{ab}$ & $77.2 \mathrm{ab}$ \\
Biofertilizers & $651 \mathrm{a}$ & $28.7 \mathrm{~b}$ & $2.0 \mathrm{~b}$ & $3.2 \mathrm{a}$ & $20.8 \mathrm{a}$ & $93.1 \mathrm{a}$ \\
$P$ values & 0.625 & 0.014 & 0.006 & 0.444 & 0.021 & 0.002 \\
\hline
\end{tabular}

The secondary and micro-nutrient status of the soil was promoted due to organic farming in comparison to conventional farming Values followed by a similar letter are not significantly different

were also higher in organic plots. Increase in soil organic matter, soil $\mathrm{pH}$, available $\mathrm{P}$ and $\mathrm{K}$ have been measured in some organic systems (Scow et al. 1994; Clark et al. 1998). Similar results have been reported in other crops under Indian conditions as well (Srivastava et al. 2006; Mahapatra et al. 2006b). Organic manures help to enhance soil $\mathrm{pH}$ in acidic soils (Mei et al. 2002; Prabhakaran and Pitchai 2002; Prakash et al. 2002).The $\mathrm{pH}$ increase under organic management may be possibly due to elimination of $\mathrm{NH}_{4}$ fertilizers and the addition of cations via manure applications. The moderating effect of organic manures like FYM, green manure, neem cake etc. on soil acidity can be attributed to decrease in the activity of exchangeable $\mathrm{Al}^{3+}$ ions in soil solution due to chelation by organic molecules thereby reducing $\mathrm{Al}$ phytotoxicity and lowering $\mathrm{Al}$ bioavailability. Moreover the Ca content in FYM $(0.14 \%)$ and ash (20-40\%) might have also contributed to a self-liming effect (Mei et al. 2002; Prabhakaran and Pitchai 2002; Prakash et al. 2002). As reported by Clark et al. (1998), the addition of green manure in organic farming may provide an additional source of cations, possibly from lower soil depths that are released at the soil surface through leaching and decomposition activities. Synthetic fertilizer application may have acidified the soil slightly in conventional systems (Barak et al. 1997).
Higher organic C status of organic plots might be attributed to considerable addition of organic manures particularly green manure cowpea. Higher available $\mathrm{N}$ status may be due to higher $\mathrm{N}$ content in the organic manures, especially green manure used in the study (FYM: $0.5 \%$, green manure cowpea: $3.45 \%$, neem cake: $1.5 \%$ ). Solubilization of native $\mathrm{P}$ by organic acids during decomposition of organic manures and increased mineralization of $\mathrm{P}$ from the added organic manures might have led to a higher available $\mathrm{P}$ in organic plots. Higher content of $\mathrm{K}$ in the organic manures, especially green manure and ash (FYM, 0.28\%; green manure cowpea, 2.02\%; neem cake, $1.2 \%$; ash, $7.11 \%$ ), $\mathrm{K}$ mining effect from the sub surface layers by the extensive root system of green manure crop of cowpea, organic acid dissolution of the rather inaccessible $\mathrm{K}$ minerals in the soil during green manure decomposition all might have contributed to higher content of available $\mathrm{K}$ in organic plots.

Among the secondary nutrients, exchangeable Mg was influenced by various practices, with significantly higher contents in organic and traditional plots (Table 2). Organic plots also had significantly higher available $\mathrm{Cu}$ content. Apart from these, available $\mathrm{Mn}$ and $\mathrm{Fe}$ contents were also significantly higher in organic plots than in conventional plots. Though exchangeable $\mathrm{Ca}$ and available $\mathrm{Zn}$ contents

Table 3 Effect of production systems on soil physical properties and microbial count

\begin{tabular}{|c|c|c|c|c|c|c|c|}
\hline $\begin{array}{l}\text { Production } \\
\text { systems }\end{array}$ & $\begin{array}{l}\text { Bulk density } \\
\left(\mathrm{g} \mathrm{cm}^{-3}\right)\end{array}$ & $\begin{array}{l}\text { Particle density }\left(\mathrm{g} \mathrm{cm}^{-3}\right) \\
\text { (At the end of } 5 \text { years) }\end{array}$ & $\begin{array}{l}\text { Water-holding } \\
\text { capacity }(\%)\end{array}$ & Porosity (\%) & \multicolumn{2}{|c|}{$\left(\right.$ Mean of 3 years $\left.\left(\times 10^{5} \mathrm{cfu}_{\mathrm{gsoil}}^{-1}\right)\right)$} & $\begin{array}{l}\text { Actinomycetes } \\
\left.\left.\text { cfu gsoil }{ }^{-1}\right)\right)\end{array}$ \\
\hline Conventional & $1.580 \mathrm{a}$ & $2.301 \mathrm{a}$ & $10.99 \mathrm{~b}$ & $31.35 \mathrm{a}$ & $60.3 \mathrm{a}$ & $28.3 \mathrm{a}$ & $11.2 \mathrm{a}$ \\
\hline Traditional & $1.522 \mathrm{a}$ & $2.379 \mathrm{a}$ & $13.99 \mathrm{a}$ & $35.94 \mathrm{a}$ & $64.8 \mathrm{a}$ & $30.7 \mathrm{a}$ & $13.3 \mathrm{a}$ \\
\hline Organic & $1.544 \mathrm{a}$ & $2.287 \mathrm{a}$ & $14.11 \mathrm{a}$ & $36.51 \mathrm{a}$ & $71.1 \mathrm{a}$ & $29.5 \mathrm{a}$ & $13.1 \mathrm{a}$ \\
\hline Biofertilizers & $1.530 \mathrm{a}$ & $2.310 \mathrm{a}$ & $10.57 \mathrm{~b}$ & $33.44 \mathrm{a}$ & $60.1 \mathrm{a}$ & $24.3 \mathrm{a}$ & $11.1 \mathrm{a}$ \\
\hline$P$ values & 0.691 & 0.859 & 0.012 & 0.305 & 0.511 & 0.163 & 0.616 \\
\hline
\end{tabular}

The physical properties of the soil and soil microbial count remained unaffected under different management systems. However, water-holding capacity became significantly higher due to continuous organic farming for 5 years

Values followed by a similar letter are not significantly different 
Table 4 Biochemical composition of corms as affected by production systems

\begin{tabular}{|c|c|c|c|c|c|c|c|}
\hline $\begin{array}{l}\text { Production } \\
\text { systems }\end{array}$ & $\begin{array}{l}\text { Dry matter } \\
(\%)\end{array}$ & $\begin{array}{l}\text { Starch } \\
\text { (\% FW basis) }\end{array}$ & $\begin{array}{l}\text { Crude protein } \\
(\% \mathrm{FW} \text { basis })\end{array}$ & $\begin{array}{l}\text { Total sugars } \\
\text { (\% FW basis) }\end{array}$ & $\begin{array}{l}\text { Reducing sugars } \\
\text { (\% FW basis) }\end{array}$ & $\begin{array}{l}\text { Total phenols } \\
\left(\mathrm{mg} 100 \mathrm{~g}^{-1}\right)\end{array}$ & $\begin{array}{l}\text { Oxalate } \\
\text { (\% DW basis })\end{array}$ \\
\hline Conventional & $19.93 \mathrm{~b}$ & $14.68 \mathrm{~b}$ & $1.82 \mathrm{a}$ & $2.38 \mathrm{a}$ & $0.78 \mathrm{ab}$ & $80.8 \mathrm{~b}$ & $0.234 \mathrm{a}$ \\
\hline Traditional & $20.72 \mathrm{ab}$ & $16.51 \mathrm{a}$ & $1.90 \mathrm{a}$ & $2.12 \mathrm{~b}$ & $0.69 \mathrm{~b}$ & $76.7 \mathrm{~b}$ & $0.217 \mathrm{ab}$ \\
\hline Organic & $21.41 \mathrm{a}$ & $16.54 \mathrm{a}$ & $2.04 \mathrm{a}$ & $1.98 \mathrm{~b}$ & $0.65 \mathrm{~b}$ & $69.7 \mathrm{a}$ & $0.186 \mathrm{c}$ \\
\hline Biofertilizers & $21.67 \mathrm{a}$ & $16.40 \mathrm{a}$ & $1.82 \mathrm{a}$ & $2.42 \mathrm{a}$ & $0.93 \mathrm{a}$ & $79.8 \mathrm{~b}$ & $0.204 \mathrm{bc}$ \\
\hline$P$ values & 0.008 & 0.001 & 0.107 & 0.002 & 0.002 & 0.041 & 0.004 \\
\hline
\end{tabular}

The average trend of 5 years indicates that organic corms had significantly higher dry matter and starch, slightly higher crude protein and significantly lower oxalate contents than conventional corms. Conventional corms contained significantly higher phenol

Values followed by a similar letter are not significantly different

were not significantly affected by the various production systems, these were slightly higher in organic plots.

It is known that $\mathrm{pH}$ is the most important determinant of soil nutrient availability. In the present study also, lowering of soil acidity might have enabled the availability of major and secondary nutrients to some extent as reported by Prakash et al. (2002). Moreover, organic manures used in the study, FYM, green manure cowpea and neem cake contain major, secondary and micro-nutrients. Deficiency of secondary and micro-nutrients $(\mathrm{Zn}, \mathrm{S}, \mathrm{B}, \mathrm{Mo}, \mathrm{Fe}, \mathrm{Mn}$ and $\mathrm{Cu}$ ) have emerged as a wide spread soil problem affecting crop productivity and profitability of farming in India (Chhonkar 2008). This is mainly due to the continuous use of high analysis fertilizers, which do not provide secondary and micro-nutrients. The present study proves that organic farming involving the use of organic manures helps to restore and improve soil health, by enhancing organic matter levels, neutralising soil acidity, supplying almost all essential nutrients in available form and thereby maintaining soil fertility.

\subsection{Soil physical properties and microbial count}

The physical properties of the soil viz., bulk density, particle density and water-holding capacity remained unaltered under the influence of the various production systems when examined after 3 years. However, bulk density was slightly lower and water-holding capacity and porosity slightly higher in organic plots. The same trend was observed at the end of 4 years, except for porosity that was significantly higher in organic plots $(37.11 \%$ as against $34.01 \%$ in conventional plots). At the end of 5 years, the water-holding capacity was significantly higher in organic plots $(14.11 \%)$ than in conventional plots (10.99\%; Table 3). Radhakrishnan et al. (2006) also observed similar results in tea gardens under the influence of organic farming. Colla et al. (2000) reported that in situ water-holding capacity was highest in organic system. Increased aeration, porosity and water-holding capacity of soils have been observed under organic management (Gerhardt 1997). Changes in organic matter drive also underpin many of the other changes in soil biological and physical properties (Stockdale et al. 2001). The increased organic matter content of soil as evidenced from higher organic C status in the organic plots in the present study might have resulted in the formation of stable soil aggregates with the resultant decrease in bulk density and increase in water-holding capacity. The soil microbial activity remained almost the same in the various treatments (Table 3).

\subsection{Corm quality}

Proximate composition Cooking quality of corms from the different production systems did not vary appreciably and

Table 5 Effect of production systems on mineral composition of corms (milligrammes per $100 \mathrm{~g}$ DW basis; mean of 5 years)

\begin{tabular}{lllllllll}
\hline Production systems & $\mathrm{P}$ & $\mathrm{K}$ & $\mathrm{Ca}$ & $\mathrm{Mg}$ & $\mathrm{Cu}$ & $\mathrm{Zn}$ & $\mathrm{Mn}$ & $\mathrm{Fe}$ \\
\hline Conventional & $455.2 \mathrm{a}$ & $1714 \mathrm{a}$ & $142.0 \mathrm{a}$ & $268.1 \mathrm{a}$ & $1.082 \mathrm{a}$ & $11.62 \mathrm{a}$ & $3.210 \mathrm{a}$ & $86.6 \mathrm{a}$ \\
Traditional & $494.6 \mathrm{a}$ & $1815 \mathrm{a}$ & $140.3 \mathrm{a}$ & $269.7 \mathrm{a}$ & $1.038 \mathrm{a}$ & $11.01 \mathrm{a}$ & $2.304 \mathrm{~b}$ & $85.9 \mathrm{a}$ \\
Organic & $427.5 \mathrm{a}$ & $1813 \mathrm{a}$ & $152.2 \mathrm{a}$ & $276.5 \mathrm{a}$ & $1.041 \mathrm{a}$ & $11.02 \mathrm{a}$ & $2.324 \mathrm{~b}$ & $71.9 \mathrm{a}$ \\
Biofertilizers & $478.6 \mathrm{a}$ & $1393 \mathrm{~b}$ & $122.2 \mathrm{~b}$ & $243.6 \mathrm{a}$ & $0.788 \mathrm{a}$ & $11.74 \mathrm{a}$ & $2.956 \mathrm{a}$ & $88.4 \mathrm{a}$ \\
$P$ values & 0.081 & 0.001 & 0.011 & 0.554 & 0.538 & 0.531 & 0.001 & 0.607 \\
\hline
\end{tabular}

Mineral composition of corms did not vary much, except for slightly higher $\mathrm{K}$ and Ca contents in organic corms and significantly higher Mn content in conventional corms

Values followed by a similar letter are not significantly different 


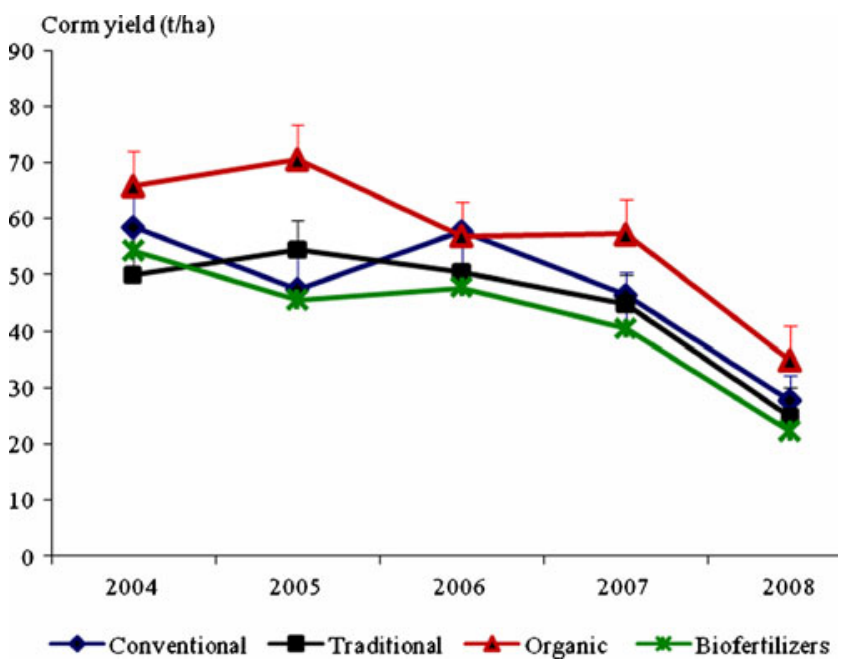

Fig. 5 Effect of production systems on corm yield of elephant foot yam over 5 years

the corms tasted equally good. Pooled analyses of biochemical constituents of corms viz., dry matter, starch, crude protein, total sugar, reducing sugar, total phenols and oxalates revealed that production systems significantly influenced these attributes. Dry matter and starch contents of organic corms, which were on par with that produced by traditional practice and using biofertilizers, were significantly higher than those of conventional corms (Table 4).

It was indicated in the present study that the treatments that were strictly organic in nature had appreciably higher dry matter and starch contents. Rembialkowska (2007) reported that organic crops contain more dry matter than conventional crops. Crude protein content was not significantly affected by the different production systems, though organic corms had slightly higher content. Total sugar and reducing sugar contents of corms from biofertilizer applied plots was significantly higher, though on par with that of corms from conventional practice. The total phenol content of conventional corms was significantly higher, but on par with that of corms from traditional practice and biofertilizer application. Organically produced corms had significantly lowest oxalate content.
Mineral composition Pooled analysis of mineral content of corms during 5 years indicated that except for $\mathrm{K}, \mathrm{Ca}$ and $\mathrm{Mn}$, there was not much variation in the mineral composition of corms due to the various practices (Table 5). Radhakrishnan et al. (2006) observed that quality parameters of tea manufactured from different farming systems, including organic system, did not vary significantly. It is likely that regardless of whether the nutrients are from organic or inorganic source, plants absorb the same as inorganic ions and once absorbed, the nutrients are resynthesized into compounds that determine the quality of the produce, which is predominantly the function of genetic makeup of the plants (Chhonkar 2008).

The organic corms had slightly higher $\mathrm{K}$ and $\mathrm{Ca}$ contents, but on par with those of conventional and traditional corms. However, Mn content of conventional corms was significantly higher than organic corms. Similar results of higher levels of $\mathrm{K}$ were observed in organic tomatoes (Pieper and Barrett 2008) and inorganic fertilizer treatment was found to significantly enhance the content of $\mathrm{Mn}$ in strawberry fruits (Hargreaves et al. 2008).

\subsection{Corm yield}

Five years of experimentation indicated the consistently superior performance of organic farming (Fig 5). During the first year, organic farming resulted in highest corm yield $\left(65.867\right.$ tha $\left.^{-1}\right)$ on par with conventional practice $\left(58.560\right.$ tha $\left.^{-1}\right)$. During the second year also, organic farming continued its superiority $\left(70.625\right.$ tha $\left.^{-1}\right)$ followed by traditional practice $\left(54.540\right.$ tha $\left.^{-1}\right)$. In the third year, organic farming was on par with conventional practice (56.948 and 57.812 tha $^{-1}$, respectively). During the fourth year, organic farming produced higher corm yield $\left(57.23 \mathrm{tha}^{-1}\right)$, on par with conventional practice $\left(46.40\right.$ tha $\left.^{-1}\right)$. During the fifth year also, organic farming continued its superiority, producing significantly higher corm yield (34.813 tha $\left.{ }^{-1}\right)$ compared to conventional practice $\left(27.779\right.$ tha $\left.^{-1}\right)$. Traditional practice

Table 6 Yield and economic advantage of organic farming over other production systems

\begin{tabular}{|c|c|c|c|c|c|}
\hline Production systems & $\begin{array}{l}\text { Mean corm weight (kg plant }{ }^{-1} \text { ) } \\
\text { (Pooled mean of } 5 \text { years) }\end{array}$ & Corm yield $\left(\mathrm{t} \mathrm{ha}^{-1}\right)$ & $\begin{array}{l}\text { Gross income } \\
\left(\text { Rs. } \mathrm{ha}^{-1}\right)\end{array}$ & $\begin{array}{l}\text { Gross costs } \\
\left(\text { Rs. ha }{ }^{-1}\right)\end{array}$ & $\begin{array}{l}\text { Net income } \\
\left(\text { Rs. ha }{ }^{-1}\right)\end{array}$ \\
\hline Conventional & $3.906 \mathrm{~b}$ & $47.609 \mathrm{~b}$ & 380872 & 212812 & 168060 \\
\hline Traditional & $3.691 \mathrm{bc}$ & $44.964 \mathrm{bc}$ & 359680 & 218800 & 140880 \\
\hline Organic & $4.689 \mathrm{a}$ & $57.097 \mathrm{a}$ & 456776 & 241000 & 215776 \\
\hline Biofertilizers & $3.454 \mathrm{c}$ & $42.066 \mathrm{c}$ & 336528 & 216240 & 120288 \\
\hline$P$ values & 0.001 & 0.001 & & & \\
\hline
\end{tabular}

Organic farming produced $20 \%$ higher yield and $28 \%$ higher net income over conventional practice

Values followed by a similar letter are not significantly different 
and plots that received biofertilizers produced almost similar yields (24.838 and 22.221 tha $^{-1}$, respectively).

Pooled analysis of corm yield of 5 years confirmed that organic farming resulted in significantly higher yield (57.097 tha $^{-1}, 4.689 \mathrm{~kg}$ plant $^{-1}$ ) in elephant foot yam (Table 6). Similar results were reported in Basmati rice (Mahapatra et al. 2006a) and in lentil, chick pea and wheat (Mahapatra et al. 2006b). Traditional practice and biofertilizer applied plots, which were also strictly organic in nature, remained on a par and produced significantly lower yields (44.964 and 42.066 tha $^{-1}$, respectively). Organic farming $\left(57.097 \mathrm{tha}^{-1}\right)$ resulted in $20 \%$ higher yield over conventional practice (47.609 tha $^{-1}$; yield increase of $9.5 \mathrm{tha}^{-1}$ ). This may be attributed to the overall improvement in soil physico-chemical properties due to addition of various organic sources of nutrients. Kabeerathumma et al. (1987) reported that a crop of elephant foot yam yielding 33 tha $^{1}$ of tubers was found to remove $128.8 \mathrm{~kg} \mathrm{~N}, 23.6 \mathrm{~kg} \mathrm{P}_{2} \mathrm{O}_{5}$ and $239.6 \mathrm{~kg} \mathrm{~K} \mathrm{~K}_{2} \mathrm{O}$ per hectare indicating that it is a nutrient exhausting crop and proper replenishment of soil with adequate amounts of nutrients is required for getting sustained higher yield. The present study indicates that even in the absence of chemical fertilizers, higher yield can be obtained by proper supplementation of nutrients through cheaper and easily available organic sources, based on soil testing. The yield increase observed in this study conducted for five consecutive years is contrary to some of the reports that crop yields under organic management are 20-40\% lower than for comparable conventional systems (Stockdale et al. 2001). However, the present study indicates that there is great scope for organic farming in tropical tuber crops, especially elephant foot yam.

\subsection{Economic analysis}

Of the various production systems tested, organic farming generated the highest net income of Rs. $215,776 \mathrm{ha}^{-1}$ as against Rs. $168,060 \mathrm{ha}^{-1}$ under the conventional system (Table 6). The higher net income from organic farming is due to the $20 \%$ extra yield obtained over conventional practice (yield increase of $9.5 \mathrm{tha}^{-1}$ ) generating an additional income of Rs. $47,716 \mathrm{ha}^{-1}$. Based on the present study the organic farming technology package was standardized for elephant foot yam as follows: farmyard manure; $36 \mathrm{tha}^{-1}$, green manuring with cowpea to generate $20-25$ tha $^{-1}$ of green matter in 45-60 days; neem cake, 1 tha $^{-1}$ and ash, 3 tha $^{-1}$.

\section{Conclusion}

Organic farming is a feasible strategy in elephant foot yam for getting higher yield of quality tubers and safe food besides maintaining soil fertility and soil health. On farm, generation of cheap organic manures like green manures, composts, crop residues etc. will help to make organic farming profitable. This farming strategy also resulted in a healthy crop stand without collar rot disease, $20 \%$ higher corm yield and additional returns over conventional practice.

Organic corms had significantly higher dry matter and starch, slightly higher crude protein, $\mathrm{K}$ and $\mathrm{Ca}$ contents and significantly lower oxalate content. The physico-chemical properties of soil were also favoured under organic farming. The study proves that for a highly nutrient exhausting crop like elephant foot yam, higher yield can be obtained by using cheaper and easily available organic manures based on soil testing. The green manuring with cowpea is a cost effective practice that could form the main component of any organic farming program.

Generation of sufficient biomass in and around the farms, development of biogas plants and agro-forestry, addition of crop residues, green manuring, recycling of on-farm and off-farm wastes, enhancing nutrient value of manures through composting, adoption of crop rotations involving legumes etc. are some of the strategies that will help to promote organic farming of tuber crops, in rain-fed and tribal areas, where these are popular as a high energy staple food.

Acknowledgements The authors gratefully acknowledge the Director, Central Tuber Crops Research Institute for providing facilities for carrying out the research work and Mr. M. Manikantan Nair and Mrs. K. S. Sudha Devi, Technical Officers, Central Tuber Crops Research Institute for the chemical and biochemical analyses, respectively.

\section{References}

Andrews SS, Mitchell JP, Mancinelli R, Karlen DL, Hartz TK, Horwath WR, Pettygrove GS, Scow KM, Munk DS (2002) On-farm assessment of soil quality in California's central valley. Agron J 94:12-23

AOAC (1980) Official methods of analysis. Association of Official Agricultural Chemists, Washington DC., pp.169, 611-612, 1141

Barak P, Jobe B, Krueger AR, Peterson A, Laird A (1997) Effects of long term soil acidification due to nitrogen fertilizer inputs in Wisconsin. Plant Soil 197:61-69

Chhonkar PK (2008) Organic farming and its relevance in India. In: Tarafdar JC, Tripathi KP, Mahesh K (eds) Organic agriculture. Scientific Publishers Jodhpur, India, pp 5-33

Clark MS, Horwath WR, Shennan C, Scow KM (1998) Changes in soil chemical properties resulting from organic and low-input farming systems. Agron J 90:662-671

Colla G, Mitchell JP, Joyce BA, Huyck LM, Wallender WW, Temple SR, Hsiao TC, Poudel DD (2000) Soil physical properties and tomato yield and quality in alternative cropping systems. Agron J 92:924-932

Dubois M, Gilles KA, Hamilton JK, Rebers PA, Smith F (1956) Colorimetric method for determination of sugars and related substances. Analytical Chem 28:350-356 
Gerhardt RA (1997) A comparative analysis of the effects of organic and conventional farming systems on soil structure. Biol Agric Hort 14:139-157

Gupta RP, Dakshinamoorthy C (1980) Procedures for physical analysis of soil and collection of agrometeorological data. Indian Agricultural Research Institute, New Delhi

Hargreaves JC, Adl MS, Warman PR, Rupasinghe HPV (2008) The effects of organic and conventional nutrient amendments on strawberry cultivation: fruit yield and quality. J Sci Food Agric 88:2669-2675

Kabeerathumma S, Mohan KB, Nair PG (1987) Nutrient uptake and their utilization by yams, aroids and coleus. Central Tuber Crops Research Institute, Sreekariyam, Thiruvananthapuram, Technical Bulletin Series-10

KAU (2002) Kerala Agricultural University, package of practices recommendations: crops. Directorate of Extension, Mannuthy, Thrissur, pp 49-53

Mahapatra BS, Misra A, Chilana K, Kumar A, Singh SP (2006a) Growth and yield of Basmati rice under organic mode during initial years of conversion in relation to nutrient management practices. J Ecofriendly Agric 1(1):1-5

Mahapatra BS, Singh SP, Rajesh A, Vishwakarma VK, Bhushan C, Kumar A, Singh RK, Kumar A, Chilana K, Pandey CS (2006b) Performance of lentil, chickpea and wheat under organic mode during initial years of conversion in relation to nutrient management practices. J Ecofriendly Agric 1(2):105-116

Mei C, Yahua S, Zhengguo O, Qirong S (2002) Amelioration of aluminium toxicity with pig manure in an acid red soil. Plant Nutr Fert Sci 8(2):176

Nelson N (1944) A photometric adaptation of the Somogyi method for determination of glucose. J Biol Chem 153:375-380

Page AL, Miller RH, Keeney DR (1982) Methods of soil analysis, part 2: chemical and microbiological properties. American Society of Agronomy, Soil Science Society of America, Madison,Wisconsin, USA, p 1159, Agronomy series no. 9

Pieper JR, Barrett DM (2008) Effects of organic and conventional production systems on quality and nutritional parameters of processing tomatoes. J Sci Food Agric 89:177-194

Piper CS (1970) Plant and soil analysis. Hans publications, Bombay

Prabhakaran C, Pitchai GJ (2002) Effect of different organic nitrogen sources on $\mathrm{pH}$, total soluble solids, titrable acidity, reducing and non reducing sugars, crude protein and ascorbic acid content of tomato fruits. J Soils and Crops 12(2):160-166
Prakash YS, Bhadoria PBS, Rakshit A (2002) Comparative efficacy of organic manures on the changes in soil properties and nutrient availability in an alfisol. J Indian Soc Soil Sci 50 (2):219-221

Radhakrishnan B, Ranjit KQ, Ganapathy MNK, Hudson JB (2006) Effect of conventional, organic and biodynamic farming systems in tea. J Plantation Crops 34:330-333

Reganold JP, Glover JDP, Andrews K, Hinman HR (2001) Sustainability of three apple production systems. Nature 410:926-929

Regu A, Deepa VC, Sundaram KA (1999) Study on Soorana (Amorphophallus paeoniifolius) The king of tubers. In: Balagopalan C, Nayar TVR, Sundaresan S, Premkumar T, Lakshmi KR (eds) Tropical Tuber Crops in Food Security and Nutrition. Oxford and IBH Publishing Co. Pvt. Ltd, New Delhi, pp 10-14

Rembialkowska E (2007) Quality of plant products from organic agriculture. J Sci Food Agric 87:2757-2762

SAS (2008) SAS users guide. SAS Institute Inc, Cary, North Carolina, USA

Scow KM, Somasco O, Gunapala N, Lau S, Venette R, Ferris H, Miller R, Shenman C (1994) Transition from conventional to low-input agriculture changes soil fertility and biology. California Agric 48:20-26

Srivastava AK, Singh S, Shivankar VJ, Das AK, Rao CN (2006) Organic citrus status. National Research Centre for Citrus, Nagpur, Maharashtra

Stockdale EA, Lampkin NH, Hovi M, Keating R, Lennartsson EKM, Macdonald DW, Padel S, Tattersall FH, Wolfe MS, Watson CA (2001) Agronomic and environmental implications of organic farming systems. Adv Agron 70:261-327

Suja G (2008) Strategies for organic production of tropical tuber crops. In: Venkateswarlu B, Balloli SS, Ramakrishna YS (eds) Organic farming in rainfed agriculture: opportunities and constraints. Central Research Institute for Dryland Agriculture, Hyderabad, p 185

Suja G, Nayar TVR, Potty VP, Sundaresan S (2006) Organic farming: a viable strategy for high yield and quality tuber crop production. Indian Hort 51(6):4-5

Swain T, Hillis WE (1955) The phenolic constituents of Prumus domestica 1 . The quantitative analysis of phenolic constituents. J Sci Food Agric 10:963-968

Timonin MI (1940) The interaction of higher plants and soil microorganisms I. Microbial population of the rhizosphere of seedlings of certain cultivated plants. Canadian J Res 181:307-317 